development of CHD in postmenopausal women. Such studies are planned but until the results are known we can only remark that if a therapy that seemed to reduce CHD incidence by $50 \%$ were available to men they would be encouraged to take it.

Royal Alexandra Hospital,

Paisley

IAIN FINDLAY

Royal Brompton and

National Heart Hospital, London

Western Infirmary, Glasgow

DAVID CUNNINGHAM

HENRY J DARGIE

1 Isles CG, Hole DJ, Hawthorne VM, Lever AF. Relation between coronary risk and coronary mortality in women of the Renfrew and Paisley survey: comparison with men. Lancet 1992;339:702-6.

2 Vital statistics of the United States 1983
2 (II) Mortality part B Washington, DC: US Department of Health and Human Services Publication 87-1114, 1987.

3 Colditz GA, Walter BS, Willett WC, et al. Menopause and the risk of coronary heart disease in women. N Engl f Med 1987;316:1 105-10.

4 Wilson PW, Garrison RJ, Castelli WP. Postmenopausal estrogen use, cigarette smoking and cardiovascular disease in women over 50-the Framingham study. $N$ Engl $\mathcal{F}$ Med 1985;313:1038-43.

5 Eaker ED, Castelli WP. Coronary heart disease and its risk factors among women in the Framingham Study. In: Eaker E, Packard B, Wenger NK, Clarkson TB, Tyroler HA, eds. Coronary heart disease in women. New York: Haymarket Doyma 1987:122-32.

6 Bush TL, Barret-Connor E, Cowan LD, et al. Cardiovascular mortality and non-contraceptive estrogen use in women: results from the Lipid
Research Clinics Program Follow-up Study. Circulation 1987;75: 1102-9.

7 Stampfer M, Willett W, Corditz G, Rosner B, Speizer F, Hennekens C. A prospective of postmenopausal estrogen therapy and coronary heart disease. N Engl f Med 1985;313:1044-9.

8 Stampfer MJ, Colditz GA, Willett WC, et al. Postmenopausal estrogen therapy and cardiovascular disease: ten year follow-up from the Nurses' therapy and cardiovascular disease: ten year fo
Health Study. $N$ Engl $₹$ Med 1991;325:756-62.

9 Henderson BE, Paganini-Hill A, Ross RK. Decreased mortality in users of estrogen replacement therapy. Arch Intern Med 1991;151:75-8.

10 Barret-Connor E, Bush TL. Estrogen and coronary heart disease in women. $\mathcal{F} A M A 1991 ; 265: 1861-7$.

11 Stampfer MJ, Colditz GA. Estrogen replacement therapy and coronary heart disease: a quantitative assessment of the epidemiologic evidence Prev Med. 1991;20:47-63.

12 Gruchow HW, Anderson AJ, Barboriak JJ, Sobocinski KA. Postmenopausal use of estrogen and occlusion of coronary arteries. Am Heart $\mathcal{7} 1988 ; 115: 954-63$

13 Sullivan J, Vander Zwang R, Lemp GF, et al. Postmenopausal estrogen use and coronary atherosclerosis. Ann Intern Med 1988;108:358-63.

$14 \mathrm{McF}$ arland KF, Boniface ME, Hornung CA, Earnhardt W, Humphries J Risk factors and noncontraceptive estrogen use in women with and Risk factors and noncontraceptive estrogen use in wom
without coronary disease. Am Heart $\mathcal{f} 1989 ; 117: 1209-14$.

15 Miller VT, La Rossa JC. Sex steroids and lipoproteins. In: Redmond GP, ed. Lipids and women's health. New York: Springer-Verlag, 1990: 48-65.

16 Nabulsi AA, Folsam AR, White A, et al. Association of hormone replacement therapy with various cardiovascular risk factors in postmenopausal women. N Engl f Med 1993;328:1069-75.

17 Speroff $L$. The risk of breast cancer associated with oral contraception and hormone replacement therapy. Women's Health Issues 1992;2: 63-72.

18 Barrett-Connor E. Postmenopausal estrogen and prevention bias. Ann Intern Med 1991;115:455-6.

19 The Coronary Drug Project Research Group. Influence of adherence to treatment and response of cholesterol on mortality in the coronary drug project. $N$ Engl $\mathcal{F}$ Med 1980;303:1038-41.

\title{
COMMENTARY
}

\section{Arrhythmogenic right ventricular dysplasia: the phenotypic range defined}

In the fully expressed form seen by pathologists the diagnosis of arrhythmogenic right ventricular dysplasia is not difficult. The heart shown here (figure) is typical and it came from a 23 year old man who died suddenly while playing football. There was a history of previous palpitation. The pathology is unmistakable. The right ventricle is dilated

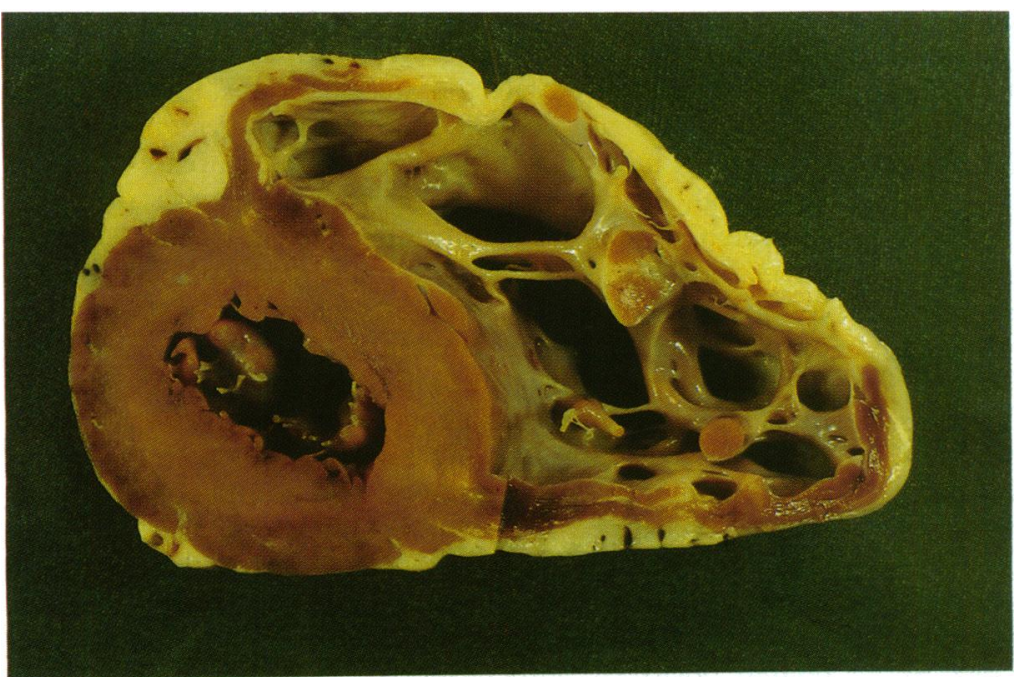

Sudden death on exercise in a man of 23. The right ventricle is dilated and in areas the wall is totally replaced by fat. and there is transmural replacement of the myocardium with fat particularly in the anterior wall. It is a truism that the pathologist sees the worst of every disease but the disease is fully expressed and easily recognised. Studies of large families show a wide clinical expression of arrhythmogenic right ventricular dysplasia in living subjects, many of whom do not have symptoms.

A classic method for defining the gene responsible for any disease is to determine its chromosomal site by linkage with other known chromosomal markers through several generations. For this to be successful, however, it needs to be certain who has the disease and who does not. Laying down a set of criteria for the diagnosis of arrhythmogenic right ventricular dysplasia is a valuable advance. The criteria will also help to establish how common arrhythmogenic right ventiruclar disease is in any particular population. In the United Kingdom the impression among pathologists is that arrhythmogenic right ventricular dysplasia is much less common than hypertrophic cardiomyopathy as a cause of sudden natural death in young adults. The ratio is thought to be lower than 1:10 but may not reflect the true frequency of the disease in living subjects.

MJ DAVIES 